\title{
Understanding misinformation infodemic during public health emergencies due to large-scale disease outbreaks: a rapid review
}

\author{
Nashit Chowdhury ${ }^{1} \cdot$ Ayisha Khalid ${ }^{1} \cdot$ Tanvir C. Turin $^{1}$ \\ Received: 26 November 2020 / Accepted: 14 April 2021 / Published online: 1 May 2021 \\ (C) The Author(s), under exclusive licence to Springer-Verlag GmbH Germany, part of Springer Nature 2021
}

\begin{abstract}
Aim The coronavirus disease 2019 (COVID-19) has caused hundreds of thousands of deaths, impacted the flow of life and resulted in an immeasurable amount of socio-economic damage. However, not all of this damage is attributable to the disease itself; much of it has occurred due to the prevailing misinformation around COVID-19. This rapid integrative review will draw on knowledge from the literature about misinformation during previous abrupt large-scale infectious disease outbreaks to enable policymakers, governments and health institutions to proactively mitigate the spread and effect of misinformation.

Subject and methods For this rapid integrative review, we systematically searched MEDLINE and Google Scholar and extracted the literature on misinformation during abrupt large-scale infectious disease outbreaks since 2000. We screened articles using predetermined inclusion criteria. We followed an updated methodology for integrated reviews and adjusted it for our rapid review approach.

Results We found widespread misinformation in all aspects of large-scale infectious disease outbreaks since 2000, including prevention, treatment, risk factor, transmission mode, complications and vaccines. Conspiracy theories also prevailed, particularly involving vaccines. Misinformation most frequently has been reported regarding Ebola, and women and youth are particularly vulnerable to misinformation. A lack of scientific knowledge by individuals and a lack of trust in the government increased the consumption of misinformation, which is disseminated quickly by the unregulated media, particularly social media.

Conclusion This review identified the nature and pattern of misinformation during large-scale infectious disease outbreaks, which could potentially be used to address misinformation during the ongoing COVID-19 or any future pandemic.
\end{abstract}

Keywords Misinformation $\cdot$ Disinformation $\cdot$ Pandemic $\cdot$ Infodemic $\cdot$ Outbreak $\cdot$ COVID- $19 \cdot$ Health literacy

\section{Background}

The severe acute respiratory syndrome coronavirus 2 (SARS$\mathrm{CoV}-2)$ is a novel virus in the coronavirus family causing the coronavirus disease 2019 (COVID-19) (Okan et al. 2020). COVID-19 was first reported in December 2019 and has since

Tanvir C. Turin

chowdhut@ucalgary.ca

Nashit Chowdhury

nashit.chowdhury@ucalgary.ca

Ayisha Khalid

ayisha.khalid1@ucalgary.ca

1 Department of Family Medicine, Department of Community Health Sciences, Cumming School of Medicine, University of Calgary, G012F, Health Sciences Centre, 3330 Hospital Drive NW, Calgary, AB T2N 4N1, Canada evolved into the sixth large-scale worldwide outbreak of the twenty-first century following the Severe Acute Respiratory Syndrome (SARS) outbreak in 2002 (Felter 2020). Estimates suggest that COVID-19 is nearly twice as contagious as the seasonal flu and takes much longer to present symptoms, making transmission of the virus through asymptomatic carriers a substantial public health challenge (Tosta 2020). Given the lack of widespread use of a safe and effective vaccine against COVID-19, public compliance with measures, such as physical distancing, hand hygiene and wearing masks, is essential to intercepting transmission links (Cheng et al. 2020). Dissemination and consumption of clear, consistent and credible information about COVID-19 is a prerequisite to public compliance with these preventative measures (Van den Broucke 2020).

Both the dissemination and consumption of information have spiked since the COVID-19 pandemic (Zarocostas 2020). During the Munich Security Conference in February 
2020, the Director-General of the World Health Organization (WHO) urged, 'we're not just fighting an epidemic; we're fighting an infodemic" (World Health Organization 2020). Infodemic is short for 'information epidemic', depicting the rapid spread and amplification of vast amounts of valid and invalid information (Okan et al. 2020). The Internet, social media and other communication platforms have eroded traditional vertical health communication strategies by allowing misinformation to horizontally diffuse faster than ever before (Wang et al. 2019; Cuan-Baltazar et al. 2020). The infodemic makes it difficult for the public to comply with public health measures, as it can debilitate individuals' ability to distinguish mis- and disinformation from fact and cause false perceptions of true risk, including both a higher perceived risk and a false sense of safety (Van den Broucke 2020; Okan et al. 2020). The spread of misinformation can also incite fear and panic, which has been found to induce mistrust in government and non-government institutions leading the pandemic response and further increase susceptibility to misinformation, conspiracy theories and rumours (Wang et al. 2019). Examining the past spread of misinformation during large-scale disease outbreaks can inform initiatives to tackle the spread of misinformation during the COVID-19 pandemic and ultimately improve public compliance with essential preventative health measures. We conducted a rapid integrative review to quickly synthesize existing literature about misinformation during recent abrupt large-scale infectious disease outbreaks, which we hope will enable policymakers, governments and health institutions to proactively mitigate the spread of misinformation during the current pandemic.

\section{Methods}

\section{Rapid integrative review}

A rapid review generates knowledge promptly by skipping some of the steps involved in a systematic review by simplifying the overall review process to produce a quick result (Khangura et al. 2012). This approach to knowledge synthesis is useful to explore a new frontier of research, update previous research knowledge, and provide a quick overview of a certain topic where time constraints exist to be able to convey the results to policymakers and/or translate the knowledge into action swiftly. This rapid integrative review primarily followed the integrative rapid review methodology developed by Whittemore and Knafl (2005) with adjustments suggested by other authors for a rapid review (Khangura et al. 2014; Tricco et al. 2015). As integrative reviews synopsise previous scientific literature to obtain a comprehensive concept of a particular research topic (Broome 2000), this approach has been deemed best fitting for this review. The review strategy is described below.

\section{Problem identification}

For this rapid review, we identified the following research questions:

1. What research has been undertaken regarding the spread of misinformation during abrupt large-scale infectious disease outbreaks in the past 20 years?

2. What factors determine the spread of misinformation among communities?

3. What sources of information are associated most with the spread of misinformation?

4. What aspects of a disease outbreak were affected by the misinformation (i.e. preventive behaviour, treatment, vaccine, etc.)?

\section{Study selection}

To extract the relevant studies on misinformation during recent abrupt large-scale infectious disease outbreaks, we used specific search terms and selected those databases that would best ensure the inclusion of sufficient relevant studies. We included the following disease outbreaks in our study per our search criteria: Severe Acute Respiratory Distress Syndrome (SARS), H1N1 Influenza (swine flu), Ebola, Zika virus, Middle East Respiratory Syndrome (MERS), and COVID-19. We followed the PICOS structure (Table 1) to determine our inclusion criteria for this review. We did not limit studies to a particular country. However, we restricted the time of publication to the past 20 years (2001 to 2020). We included studies published in the English language only.

\section{Literature search}

The research team selected the two most appropriate databases from which to mine the information relevant to the research focus of this review. MEDLINE (Ovid) was selected as the richest academic database for infectious disease outbreaks. However, as misinformation during a pandemic/epidemic often involves research articles from multiple disciplines, including social and political sciences and education and geography, and non-peerreviewed publications, we included a search of the grey literature to capture literature on misinformation during disease outbreaks from those sources. Moreover, grey databases also help extract unpublished or in-progress studies. We selected Google Scholar, which is very commonly used to capture grey literature and can extract studies indexed in other databases as well (Haddaway et al. 2015; Vaska et al. 2019). A complete list of search terms is provided in Table 2. In addition, we also conducted single citation searches and used a pearl growing approach by 
Table 1 Inclusion and exclusion criteria

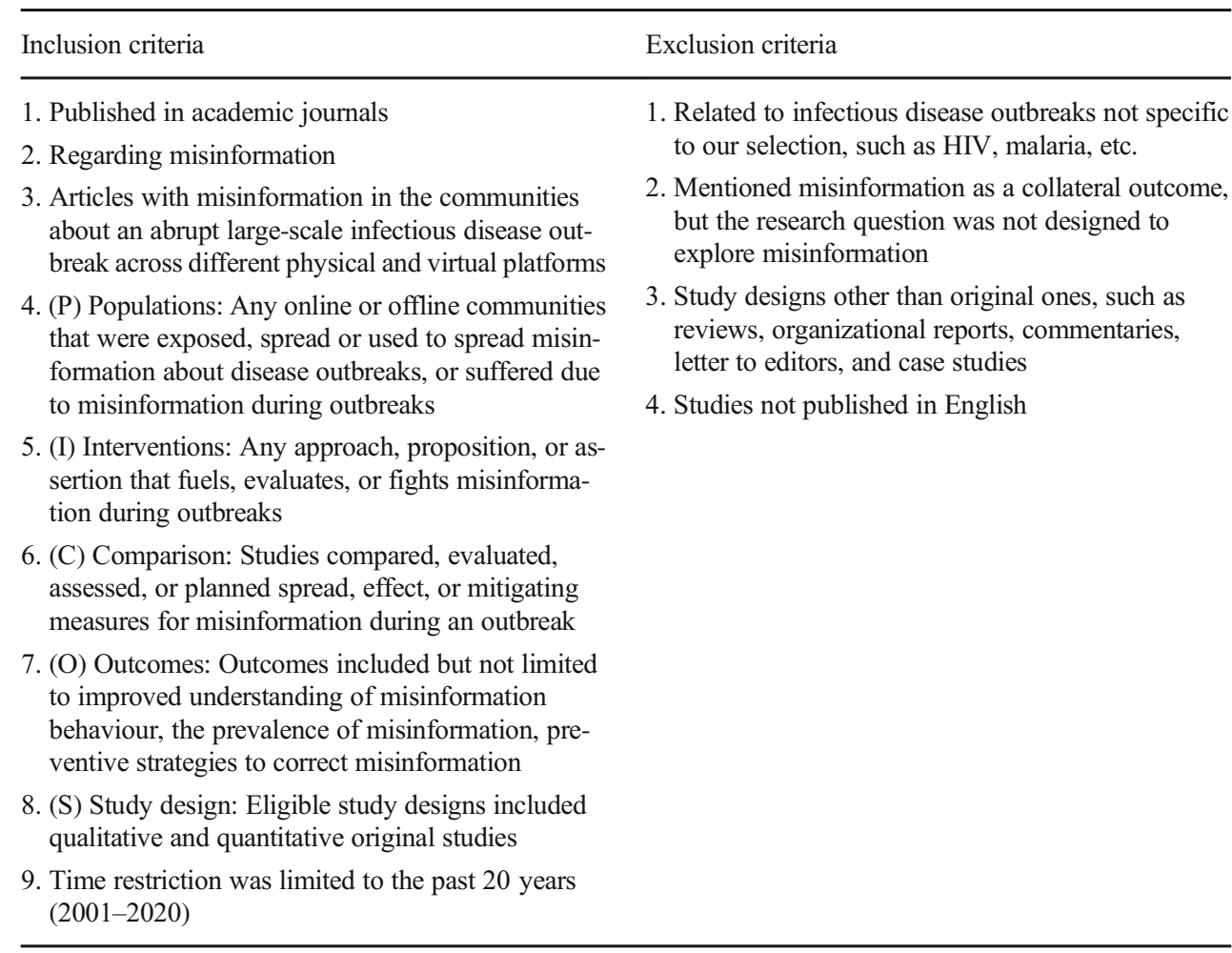

reviewing the reference lists of all selected publications to ensure all relevant articles were included.

\section{Screening}

We screened all search outcomes through a two-step process: (i) title-abstract review, and (ii) full-text review (Fig. 1). As suggested in the common rapid review strategies (Tricco et al. 2015), only one reviewer of the research team screened the studies following the two-step process (the title-abstract screening and full-text screening. In the first screening step, the reviewer screened the papers based on the relevance of their titles and abstracts to our research question. After title-abstract screening, relevant abstracts and those from which the reviewer could not draw conclusions alone were included for further review. The full texts of the eligible abstracts were studied thoroughly for inclusion in the rapid review if found relevant to the research questions. Any indecision regarding an article to include or not were resolved by the team consensus.

\section{Data extraction}

The research team reviewer extracted relevant information using a limited and predetermined abstraction tool. Firstly, study characteristics were extracted, including citations, study location, study method, study objective and study sample (Table 3).
Further data on the specific disease outbreak, the misinformation arising around the disease, how the misinformation or misconceptions were addressed, factors determining the spread of misinformation and sources of mis/information were abstracted following emergent coding (Table 4). EndNote and Microsoft Excel were used in different stages of the study.

\section{Data analysis}

The final stage of a rapid review brings together the findings from all eligible articles to deliver an evidence-based response to the original research question. Data were collected, synthesised and presented using summary tables. Extracted data were charted and examined to identify any patterns of information in the articles. The results of this process were further examined to identify key themes. Table 4 details the key findings of each paper regarding misinformation during the outbreaks of interest.

\section{Results}

\section{Literature search overview}

Our systematic search of MEDLINE identified 533 articles. We found an additional 398 articles in our grey literature search of Google Scholar. After removing duplicates, 853 
Table 2 Search terms and databases

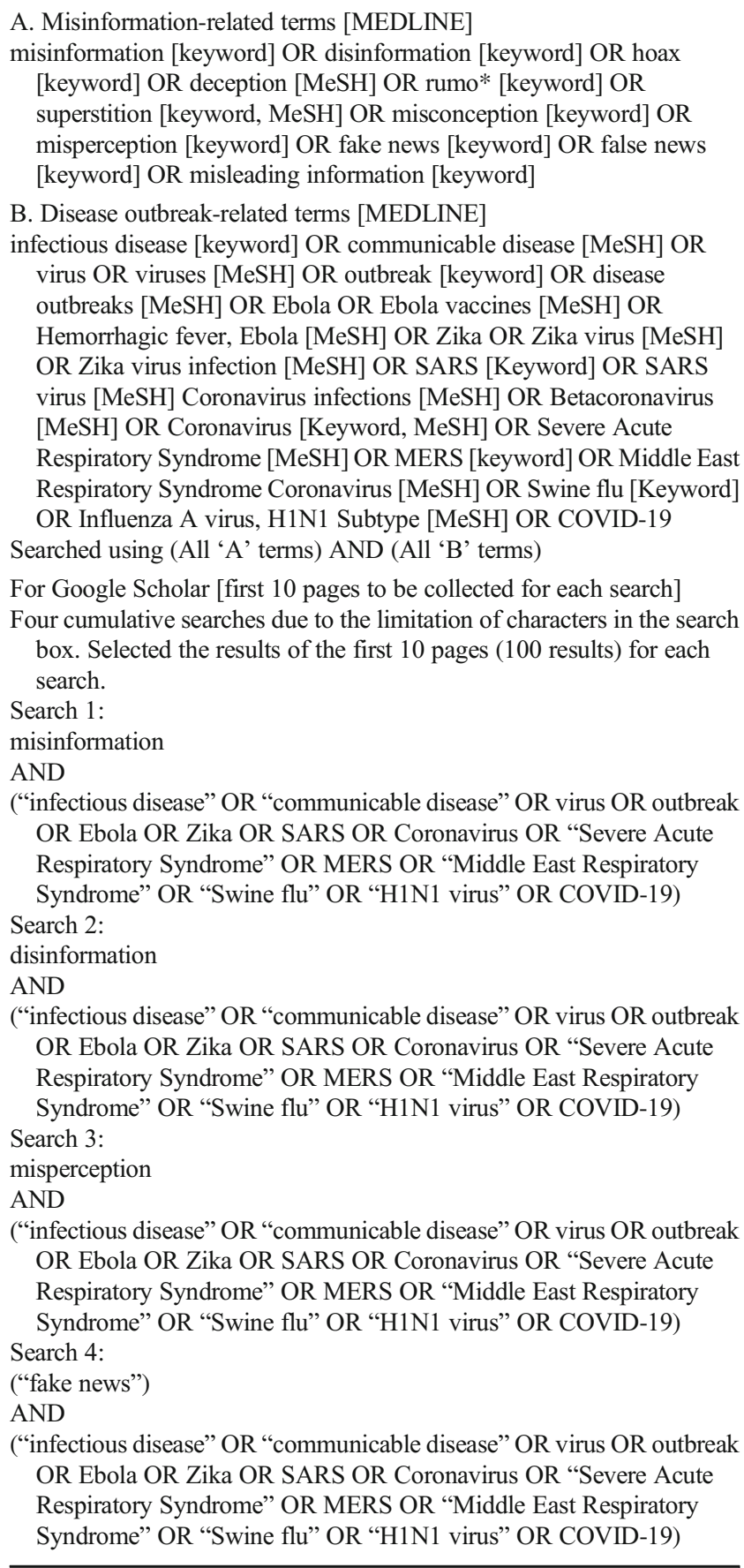

articles were identified for title and abstract screening. After reviewing the titles and abstracts, 118 articles were chosen for full-text screening. Through full-text screening, 37 articles were considered eligible for the study (Fig. 1).

\section{Content overview}

Table 3 illustrates the study contents we extracted from the studies included in this review. Most studies were conducted in the United States (12 of 37) followed by Canada and Nigeria. Thirty-four of 37 studies were published between 2011 and 2020. The study population of the studies were diverse, including physicians, school teachers, youth and students, general community members.

\section{Objectives of the studies}

A number of studies analysed content from social and mainstream media and other document sources. The majority of the studies focused on social media and the spread of information and misinformation across different social media platforms. There were also studies that assessed the knowledge, beliefs, practices and behaviour of community people during a widespread disease outbreak (Table 3). The effects of misinformation during a pandemic, the role of different information sources for risk communication, or multiple aspects of the rumour process were evaluated by some of the selected studies.

\section{Data source and collection strategies}

Overall, most of the studies collected data directly from individuals through surveys, focus groups and interviews $(n=21)$. The majority of them collected data from community individuals using surveys $(n=16)$. Three studies used both surveys and focus groups, one study used both surveys and interviews, and only one undertook only interviews. Eleven studies performed a content analysis of various social media, including Facebook, Twitter, YouTube, Sina Weibo, Reddit, Gab, LinkedIn, Pinterest, GooglePlus, Instagram and Flicker. Most of these studies analysed multiple platforms; however, Twitter was the most common social platform analysed in the studies $(n=11)$. Five other studies analysed the content of mass media, including online news sites and mainstream newspapers. One study conducted surveys and interviews and content analysis of social media.

\section{Sources of information}

In our rapid review, we sought to extract those sources from which people receive information during an outbreak. In studies conducted within the community, participants described receiving a range of information sources. In the case of social media (predominantly content analysis), some studies reported social media as a direct source, whereas others reported the original source of shared content on social media as the information source, usually given as a link/reference on a particular social media post. Overall, the most commonly reported sources of information were mass media $(n=17)$. Among mass media, the most common source of information was the mainstream news agency $(n=9)$, followed by TV $(n=4)$ and radio 


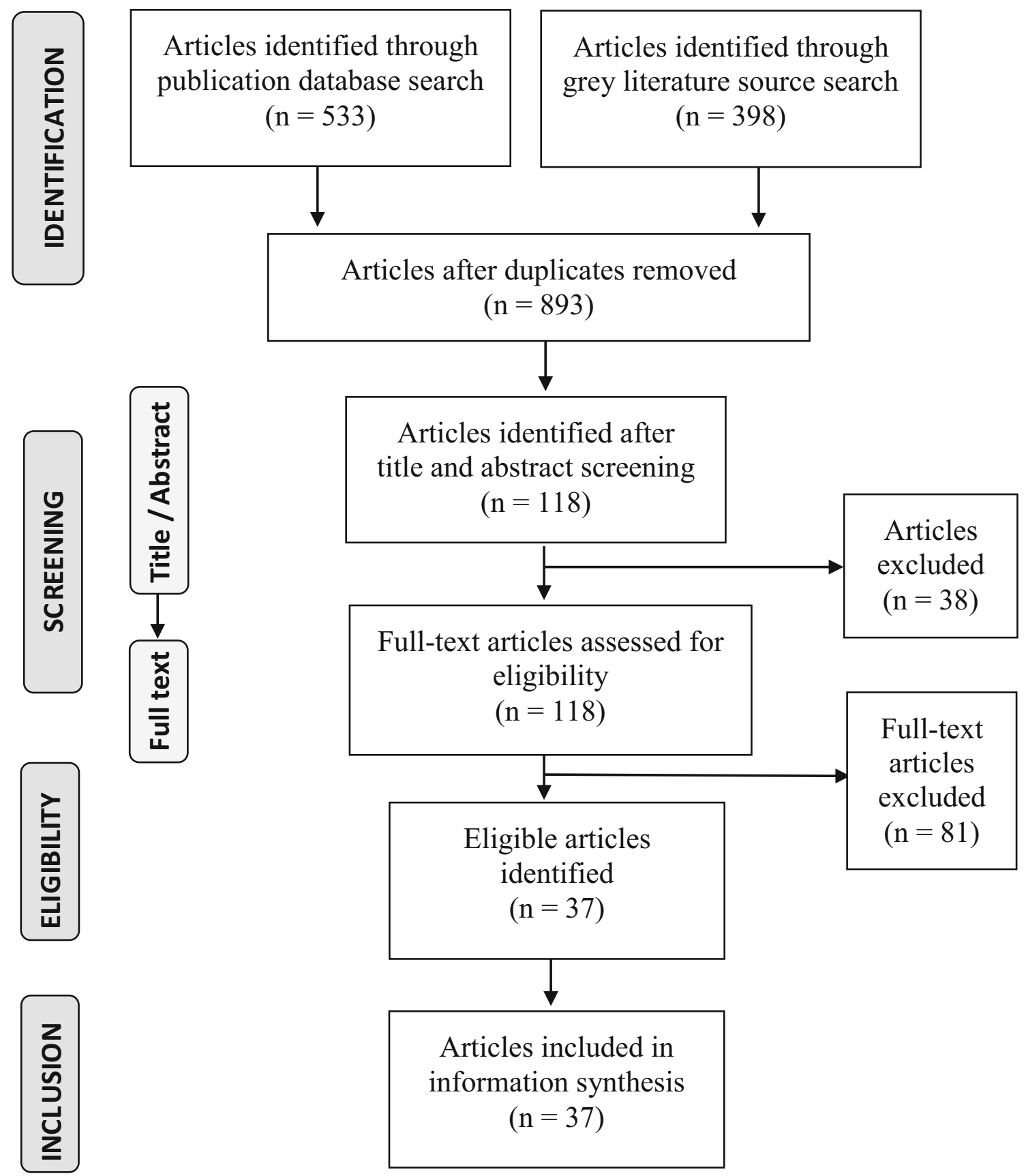

Fig. 1 PRISMA diagram for the selected studies regarding misinformation during large-scale disease outbreaks of the twenty-first century

$(\mathrm{n}=4)$, and unspecified mass media $(n=3)$. Three studies reported social media in general as the source of information. Twitter was reported in four studies, Facebook in two studies, and YouTube and Instagram in one study each. Official/government health information sites were reported in six studies. Alternative internet-based news media and blogs were reported in four studies and emergency texting was mentioned in only one study. Other sources included friends and family $(n=4)$, healthcare providers $(n=4)$, religious leaders $(n=1)$ and word of mouth $(n=2)$.
The prevalence of misinformation among individuals and information sources

We also extracted the percentage of people (if the data source was individuals) and percentage of sources (if the data source was social/mass media or other documents) having misinformation and/or a lack of proper knowledge about the diseases. Overall, among individuals, the level of misinformation ranged from approximately $30 \%$ to $88 \%$, as reported in the studies. Regarding various online and offline content, $2 \%$ to $23.8 \%$ of the content was reported as misinformation. 


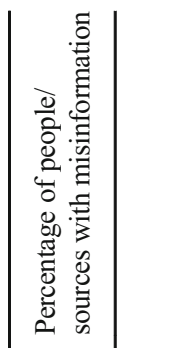
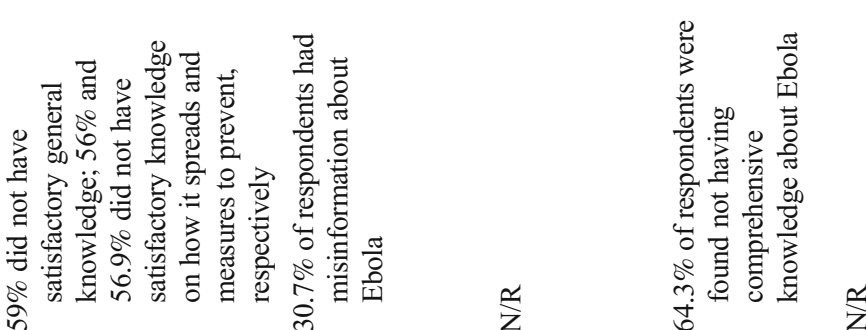

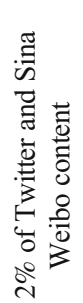

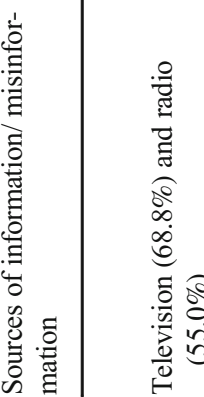
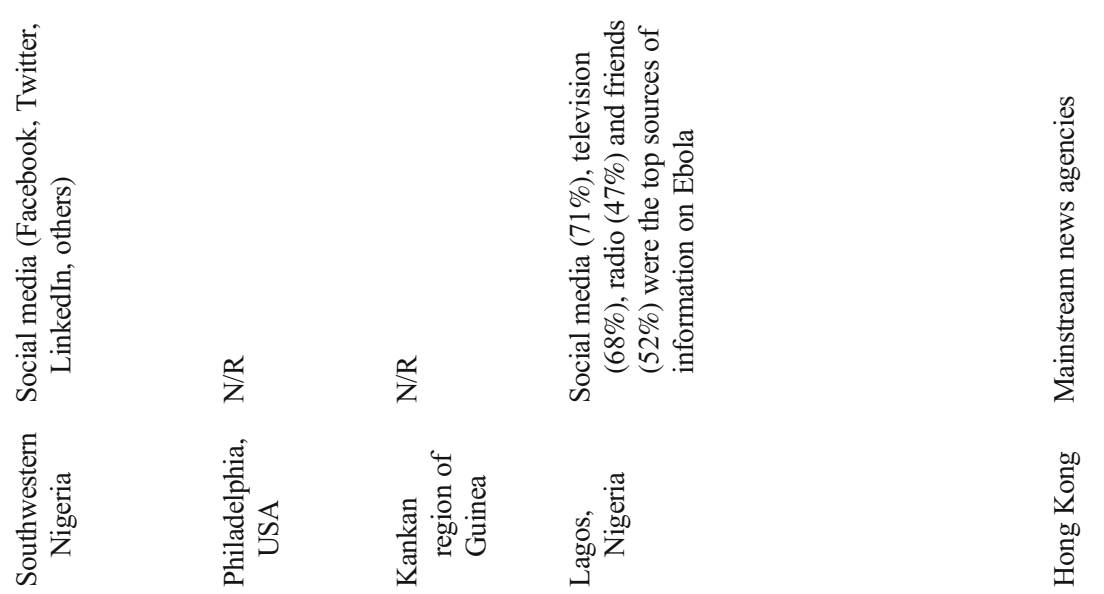

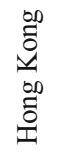

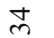

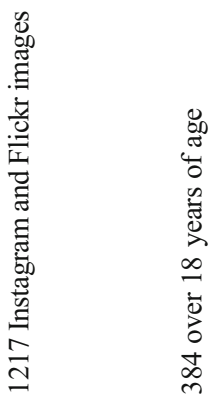

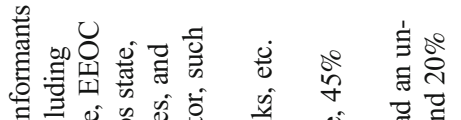

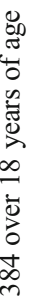

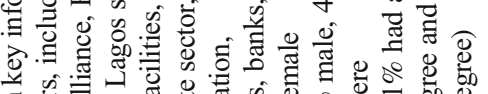

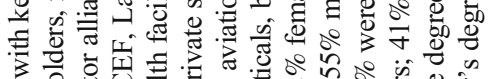

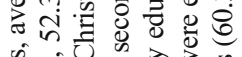

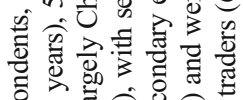

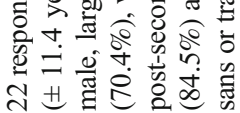
声

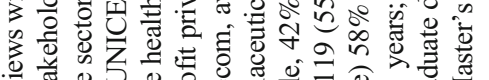

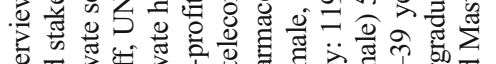

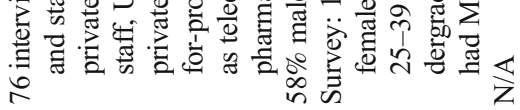
ก

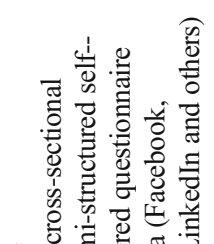

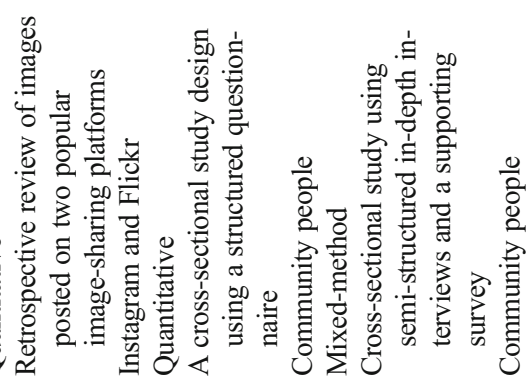

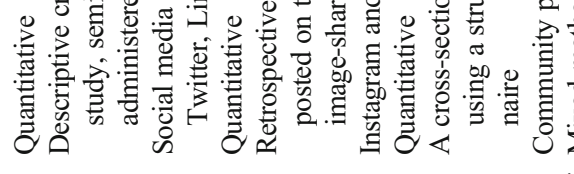
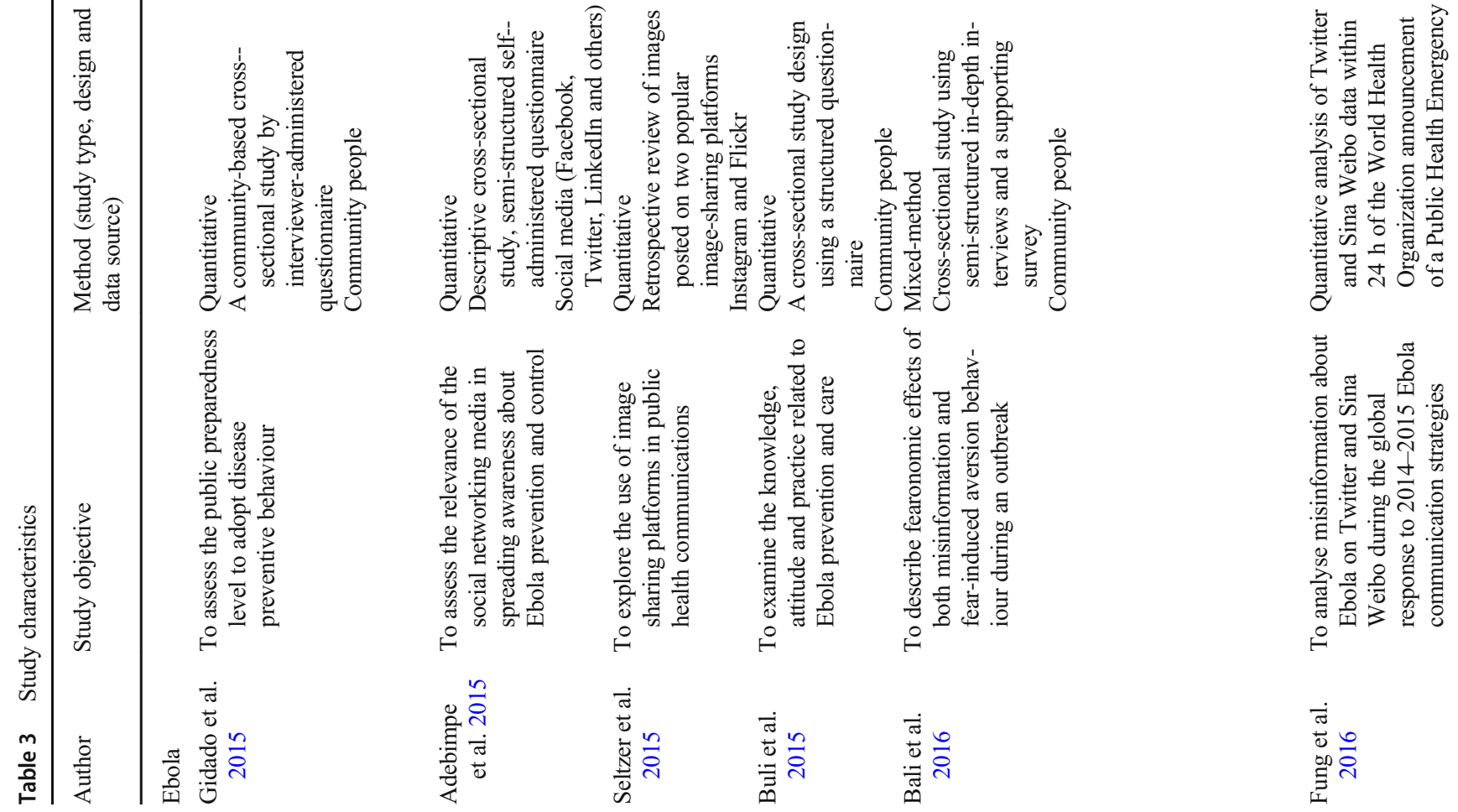
竞离
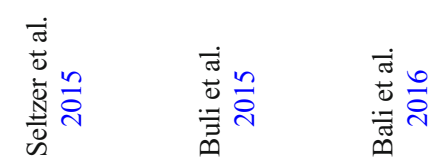

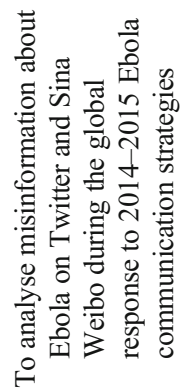




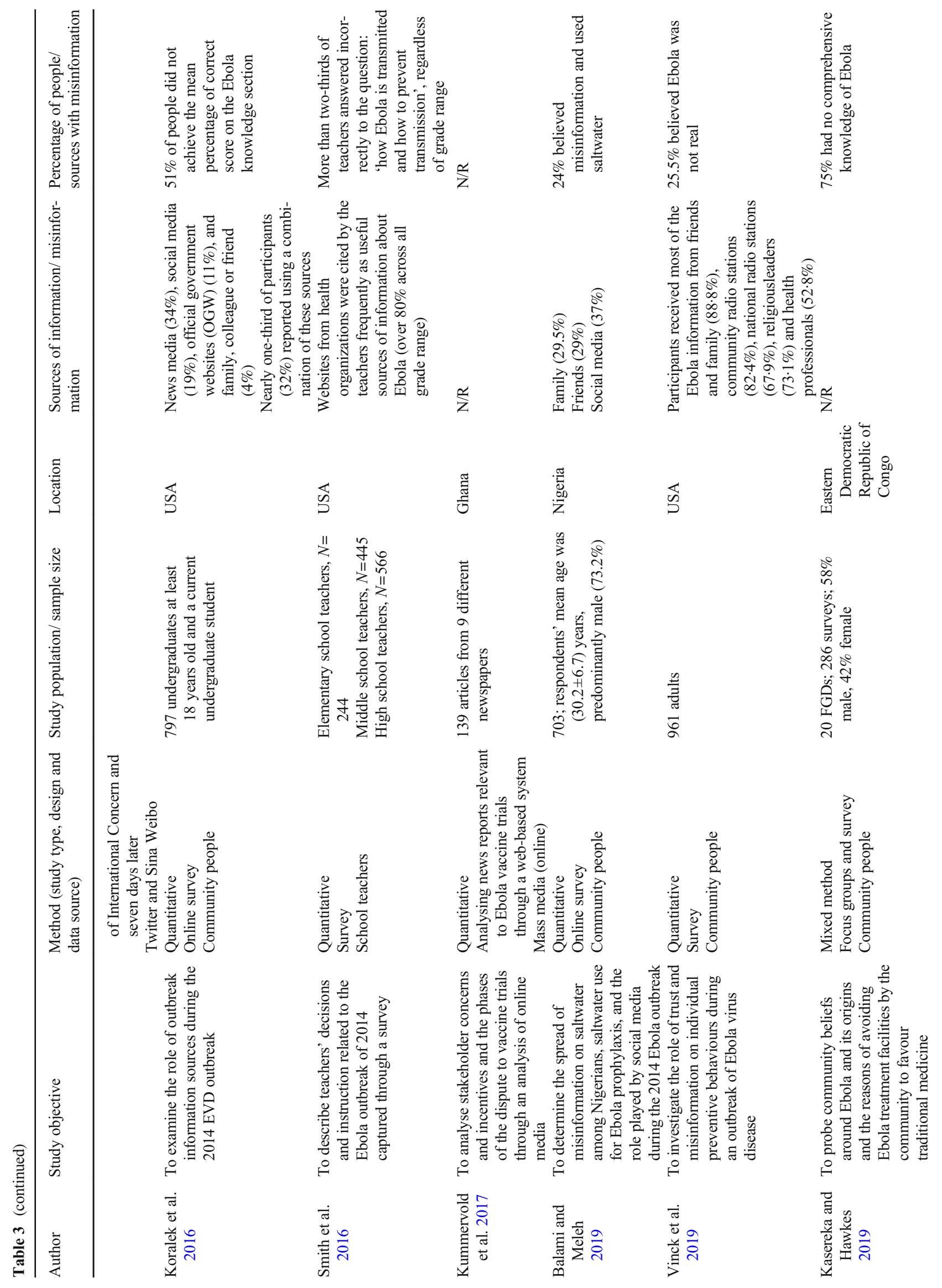




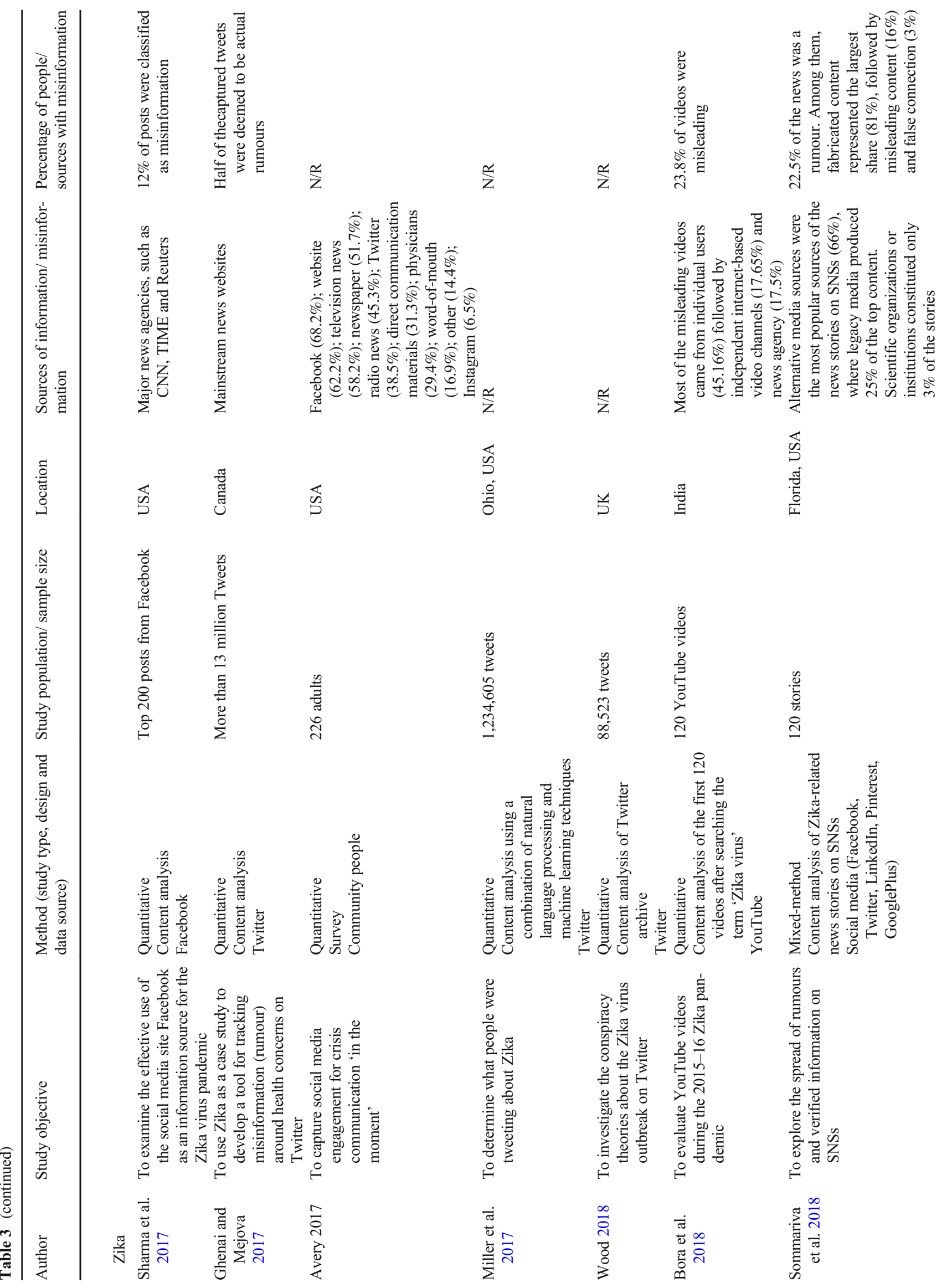




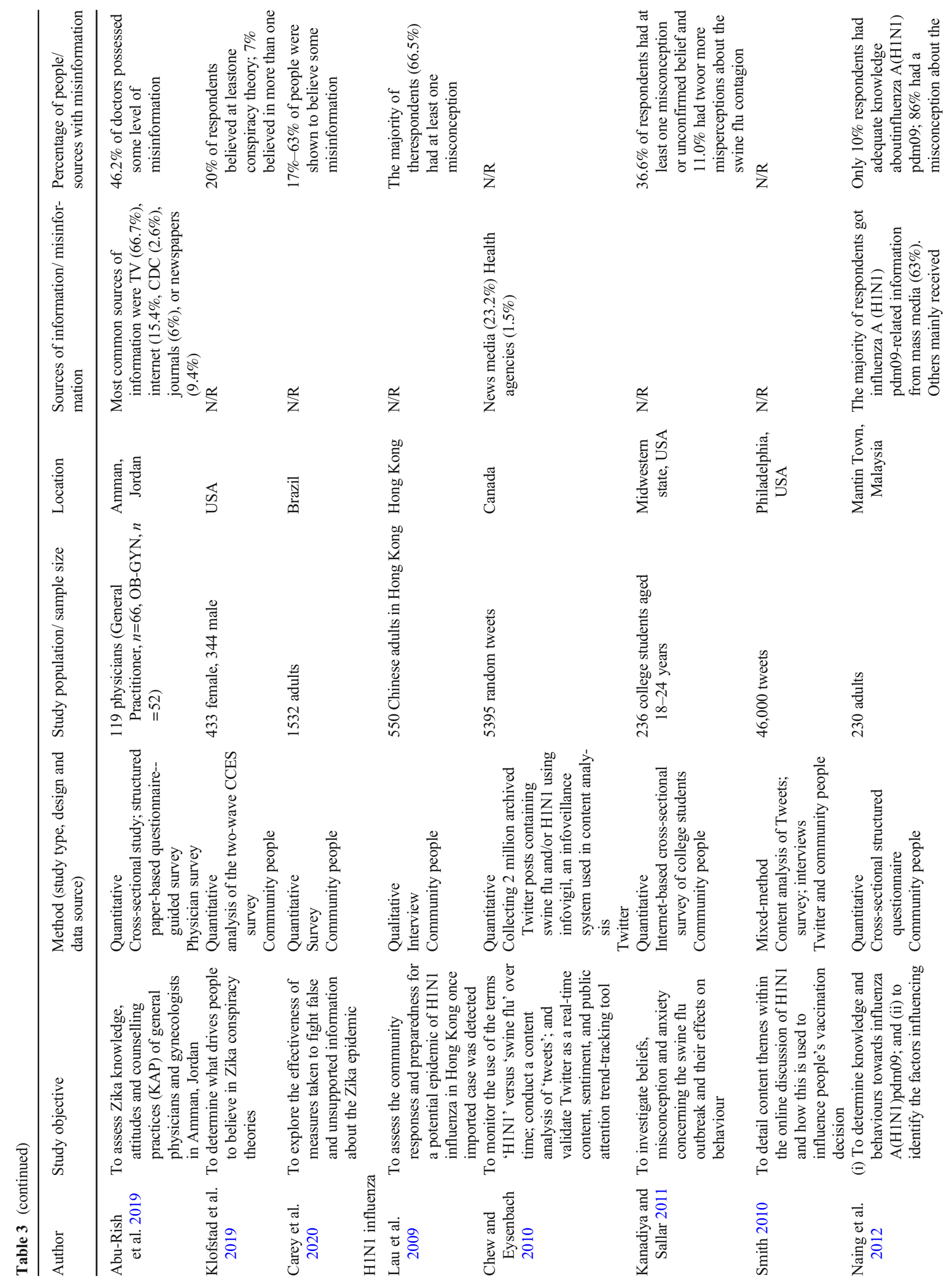




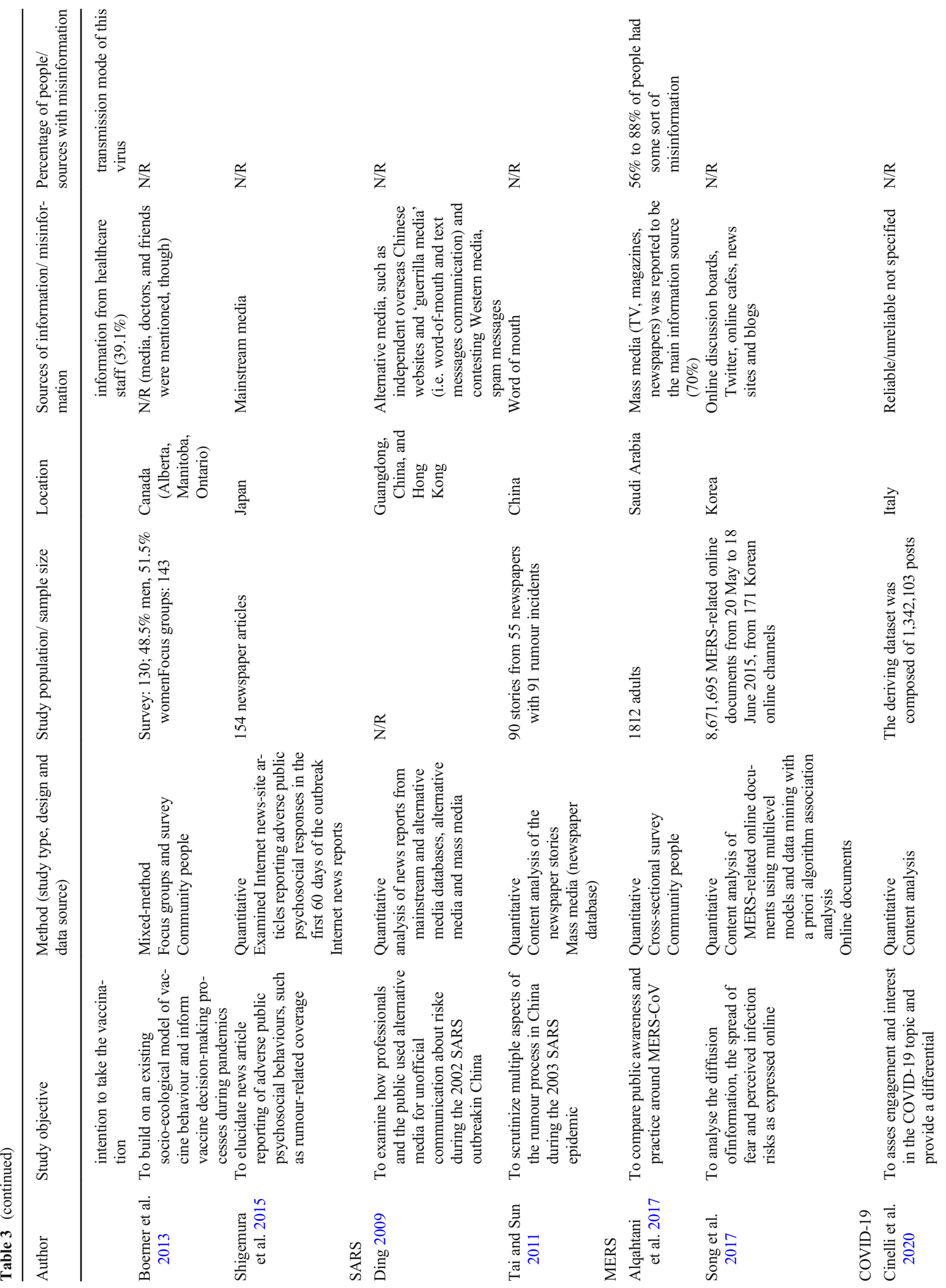




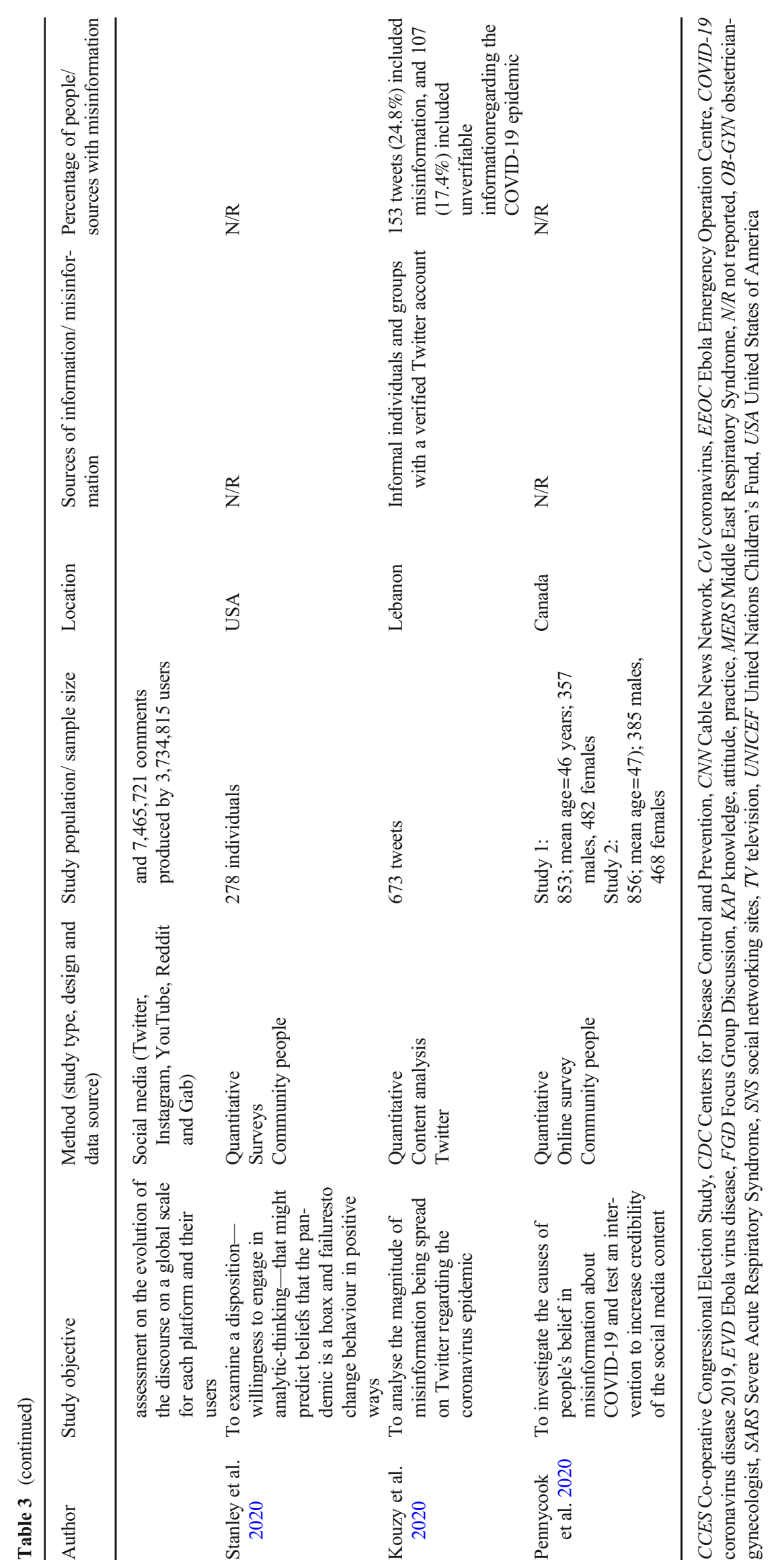




\section{Outbreaks}

Ebola was the most commonly studied outbreak that appeared in the literature. Twelve studies were conducted on the Ebola virus disease, which re-emerged extensively in 2014 (first discovered in 1976) and ran a widespread course across West Africa. The second most frequently studied disease was the Zika virus, which is a mosquito-transmitted flavivirus mostly spread from Brazil during 2015-2016. A handful of studies were found pertaining to H1N1 influenza (also known as swine flu), which had an outbreak in $2009(n=7)$. The most recent COVID-19 outbreak was the focus of research in four studies, followed by SARS $(n=2)$ and MERS $(n=2)$, whose outbreaks occurred in 2002 and 2017, respectively.

\section{Discourse of misinformation}

Various misinformation was reported in the studies eligible for this review. We attempted to catalogue them according to the different levels of outbreak response. This information is presented in Table 4.

\section{Prevention-related misinformation}

The most prevalent misinformation was about preventing Ebola by taking a daily hot water bath with salt (Adebimpe et al. 2015). Regarding the prevention of Zika, even some physicians were misinformed that Zika-infected or -exposed persons need to be isolated (Abu-Rish et al. 2019). Regarding SARS, a study in China that explored newspaper databases found 'blasting firecrackers to keep evil spirits away' was the most common piece of misinformation reported in 29 of 90 news stories they uncovered (Tai and Sun 2011). Only one prevention-related misinformation was reported about MERS, which was putting Vaseline ${ }^{\circledR}$ (petroleum jelly) under the nose, which was claimed to prevent MERS infection (Song et al. 2017).

\section{Treatment-related misinformation}

Saltwater was found as a treatment measure for Ebola across studies (Fung et al. 2016). Sixteen to $17 \%$ of people in one study believed the Zika virus can be treated with antibiotics and/or consuming a certain amount of onions (Adebimpe et al. 2015). A study on H1N1 influenza reported that many people believed since there was no definitive treatment for H1N1 influenza, there was no need for medical consultation, as that could potentially cause panic and fear among the population (Lau et al. 2009).

\section{Risk factor- and disease causation-related misinformation}

One study found that $53 \%$ of participants believed Ebola came from wild animals from forests, such as monkeys and bats (Kasereka and Hawkes 2019). A rumour claiming that lack of iodine caused SARS lead to panic buying of salt during that pandemic in China (Ding 2009). Some people who usually did not contract seasonal flu asserted they would be safe from H1N1 influenza as well, which may give them a false sense of safety and deter them from getting vaccinated (Boerner et al. 2013).

\section{Mode of transmission-related misinformation}

One study found that over two-thirds (68\%) of people believed Ebola could be spread via the mere touch of a diseased person (Bali et al. 2016). Other misinformation about mode of transmission of Ebola included consumption of pork, and transmission through air, water and food (Buli et al. 2015; Bali et al. 2016). More than half of the participants in one study among physicians $(55.9 \%)$ believed the Zika virus could be transmitted via direct contact between individuals (Abu-Rish et al. 2019).

\section{Complication-related misinformation}

In terms of misinformation about complications of disease outbreaks, the most commonly observed misinformation about Zika was that a pesticide/larvicide caused microcephaly, a complication that followed Zika virus infection in pregnant women (Miller et al. 2017; Sommariva et al. 2018).

\section{Vaccine-related misinformation}

A study in Ghana found news articles and people claming that the vaccine would cause Ebola by either the vaccine itself or the government and researchers would intentionally infect people with Ebola to test the vaccines (Kummervold et al. 2017). Two studies on H1N1 influenza found people who considered the vaccine unsafe were hindered from getting vaccinated (Kanadiya and Sallar 2011; Boerner et al. 2013).

\section{Conspiracy theories}

About one-fifth of the US citizens in one American study believed in at least one Zika conspiracy theory (Klofstad et al. 2019). The most widespread conspiracy theory about the Zika virus concerned microcephaly and that it was a complication of the Zika virus infection caused by pesticides/larvicides (Carey et al. 2020; Sharma et al. 2017) and vaccines (Wood 2018). A population-based 
Table 4 Areas of misinformation found by studies

\begin{tabular}{|c|c|c|c|}
\hline $\begin{array}{l}\text { Area of } \\
\text { misinformation }\end{array}$ & Disease & Misinformation found & Reference \\
\hline \multirow[t]{17}{*}{ Prevention } & \multirow[t]{4}{*}{ Zika } & Isolation of infected or exposed persons is required for Zika virus infection & Abu-Rish et al. 2019 \\
\hline & & Wearing long-sleeved shirts and long pants are not necessary & Abu-Rish et al. 2019) \\
\hline & & Fish can help stop Zika & Ghenai and Mejova 2017 \\
\hline & & Coffee as a mosquito repellent to protect against Zika & Ghenai and Mejova 2017 \\
\hline & \multirow[t]{7}{*}{ Ebola } & Taking daily hot water bath with salt & $\begin{array}{l}\text { Adebimpe et al. 2015; } \\
\text { Balami and Meleh 2019; } \\
\text { Buli et al. 2015; Gidado } \\
\text { et al. 2015; Kasereka } \\
\text { and Hawkes } 2019\end{array}$ \\
\hline & & Prevented by taking bitter cola/miracle cola & $\begin{array}{l}\text { Adebimpe et al. 2015; } \\
\text { Gidado et al. } 2015\end{array}$ \\
\hline & & Consumption of local medicinal herbs & Gidado et al. 2015) \\
\hline & & Ebola can be prevented by avoiding mosquito bites & $\begin{array}{l}\text { Kasereka and Hawkes } \\
2019\end{array}$ \\
\hline & & Prevented by the frequent rubbing of the body with Aloe Vera soap and cream & Adebimpe et al. 2015 \\
\hline & & Prevented by drinking plenty of condensed milk & Adebimpe et al. 2015 \\
\hline & & Preventable by not shaking hands with friends and colleagues & Adebimpe et al. 2015 \\
\hline & \multirow[t]{3}{*}{ SARS } & Blasting firecrackers keeps the evil SARS spirit away & Tai and Sun 2011 \\
\hline & & Drinking mung bean soup at midnight protects one from the viral agent & Tai and Sun 2011 \\
\hline & & Saltwater can be used for indoor disinfection when one runs out of vinegar & Ding 2009 \\
\hline & MERS & Vaseline ${ }^{\circledR}$ under the nose helps prevent MERS & Song et al. 2017 \\
\hline & COVID-19 & $\mathrm{N} / \mathrm{R}$ & \\
\hline & H1N1 & $\mathrm{N} / \mathrm{R}$ & \\
\hline \multirow[t]{11}{*}{ Treatment } & \multirow[t]{2}{*}{ Zika } & Can be treated with antibiotics & Adebimpe et al. 2015 \\
\hline & & Curable by taking an appreciable quantity of onions & Adebimpe et al. 2015 \\
\hline & \multirow[t]{3}{*}{ Ebola } & Could be successfully treated by traditional and religious healers & $\begin{array}{l}\text { Buli et al. 2015; Kasereka } \\
\text { and Hawkes } 2019\end{array}$ \\
\hline & & Bathing in or drinking saltwater & Fung et al. 2016 \\
\hline & & Ingestion of Nano Silver, an experimental drug & Fung et al. 2016) \\
\hline & \multirow[t]{3}{*}{ SARS } & An old dumb man suddenly speaks out (revealing mysterious anti-SARS prescriptions) & Tai and Sun 2011 \\
\hline & & Saltwater could kill germs and viruses & Ding 2009 \\
\hline & & A talking new-born baby reveals secret SARS-fighting recipes & Tai and Sun 2011 \\
\hline & MERS & $\mathrm{N} / \mathrm{R}$ & \\
\hline & COVID-19 & $\mathrm{N} / \mathrm{R}$ & \\
\hline & $\mathrm{H} 1 \mathrm{~N} 1$ & No treatment for $\mathrm{H} 1 \mathrm{~N} 1$ so no need for medical consultation & Lau et al. 2009 \\
\hline \multirow{9}{*}{$\begin{array}{l}\text { Risk } \\
\quad \text { factor/causes }\end{array}$} & Zika & $\mathrm{N} / \mathrm{R}$ & \\
\hline & \multirow[t]{3}{*}{ Ebola } & Witchcraft', 'magic', 'sorcerer cat', 'cat' causes Ebola & $\begin{array}{l}\text { Kasereka and Hawkes } \\
2019\end{array}$ \\
\hline & & Wild animals from the forest, monkeys, bats can cause Ebola & $\begin{array}{l}\text { Kasereka and Hawkes } \\
2019\end{array}$ \\
\hline & & $\begin{array}{l}\text { A significant proportion }(36.2 \%) \text { believed that Ebola is caused by God or other higher } \\
\text { powers }\end{array}$ & Buli et al. 2015 \\
\hline & SARS & Caused by a lack of iodine in the body & Ding 2009 \\
\hline & MERS & Individuals believed that they were under Allah's (God's) protection & Alqahtani et al. 2017 \\
\hline & COVID-19 & $\mathrm{N} / \mathrm{R}$ & \\
\hline & \multirow[t]{2}{*}{$\mathrm{H} 1 \mathrm{~N} 1$} & Being safe from seasonal flu perceived as safety from $\mathrm{H} 1 \mathrm{~N} 1$ & Boerner et al. 2013 \\
\hline & & $43.1 \%$ wrongly believed that the new H1N1 influenza is one type of avian flu & Lau et al. 2009 \\
\hline \multirow{2}{*}{$\begin{array}{l}\text { Mode of } \\
\text { transmission }\end{array}$} & \multirow[t]{2}{*}{ Zika } & Direct contact between individuals & Abu-Rishng et al. 2019 \\
\hline & & Breastfeeding as modes of transmission & Abu-Rish et al. 2019 \\
\hline
\end{tabular}


Table 4 (continued)

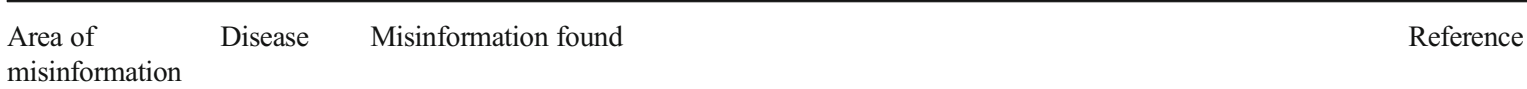

\begin{tabular}{|c|c|c|c|}
\hline & \multirow{11}{*}{ Ebola } & Eating cooked pork & Kanadiya and Sallar 2011 \\
\hline & & Eating uncooked or partially cooked poultry & Naing et al. 2012 \\
\hline & & By blood transfusion & Naing et al. 2012 \\
\hline & & Via water sources & Kanadiya and Sallar 2011 \\
\hline & & Insect bites & Kanadiya and Sallar 2011 \\
\hline & & Could spread via touch (68\%), pork consumption $(28 \%)$ and even air $(23 \%)$ & Bali et al. 2016 \\
\hline & & Transmitted by air & Buli et al. 2015 \\
\hline & & Transmitted by mosquito & $\begin{array}{l}\text { Buli et al. } 2015 \text {; Koralek } \\
\text { et al. } 2016\end{array}$ \\
\hline & & Asymptomatic carrier in an airplane can transmit & Koralek et al. 2016 \\
\hline & & Water sources & Koralek et al. 2016 \\
\hline & & Food sources & Koralek et al. 2016 \\
\hline & SARS & $\mathrm{N} / \mathrm{R}$ & \\
\hline & MERS & MERS-CoV does not transmit via camels & Alqahtani et al. 2017 \\
\hline & COVID-19 & $\mathrm{N} / \mathrm{R}$ & \\
\hline & H1N1 & Airborne via long-distance aerosols from one building to another & Lau et al. 2009 \\
\hline & & Waterborne & Lau et al. 2009 \\
\hline & & Transmission via insect bites/vectors & Lau et al. 2009 \\
\hline & & Eating well-cooked pork & Lau et al. 2009 \\
\hline \multirow[t]{8}{*}{ Complication } & Zika & Pesticide/larvicide causes microcephaly, not Zika virus & $\begin{array}{l}\text { Miller et al. 2017; } \\
\quad \text { Sommariva et al. } 2018\end{array}$ \\
\hline & & Severe disease requiring hospitalization due to Zika virus is common & Abu-Rish et al. 2019 \\
\hline & & Death from Zika virus infection is common & Abu-Rish et al. 2019 \\
\hline & Ebola & $\mathrm{N} / \mathrm{R}$ & \\
\hline & SARS & $\mathrm{N} / \mathrm{R}$ & \\
\hline & MERS & MERS is not a fatal disease (29\%) & Alqahtani et al. 2017 \\
\hline & COVID-19 & $\mathrm{N} / \mathrm{R}$ & \\
\hline & $\mathrm{H} 1 \mathrm{~N} 1$ & H1N1 has a higher fatality than SARS or avian flu & Lau et al. 2009 \\
\hline \multirow[t]{11}{*}{ Vaccine } & Zika & Microcephaly in Zika virus is caused by vaccines & $\begin{array}{l}\text { Ghenai and Mejova 2017; } \\
\text { Wood } 2018\end{array}$ \\
\hline & & Zika vaccine development efforts are part of a broader plan for global depopulation & Wood 2018 \\
\hline & Ebola & Allegation of trials being secret & Kummervold et al. 2017 \\
\hline & & Belief that the trials will lead rise of Ebola cases & Kummervold et al. 2017 \\
\hline & & Argument that incentive packages were inappropriate for the trial participants & Kummervold et al. 2017 \\
\hline & & $\begin{array}{l}\text { Suspicion that trial researchers will willingly expose the trial participants to Ebola virus to } \\
\text { test vaccines }\end{array}$ & Kummervold et al. 2017 \\
\hline & & Fear that the vaccine itself could cause Ebola & Kummervold et al. 2017 \\
\hline & SARS & $\mathrm{N} / \mathrm{R}$ & \\
\hline & MERS & $\mathrm{N} / \mathrm{R}$ & \\
\hline & COVID19 & $\mathrm{N} / \mathrm{R}$ & \\
\hline & H1N1 & The vaccine is not safe & $\begin{array}{l}\text { Boerner et al. 2013; } \\
\text { Kanadiya and Sallar } \\
2011\end{array}$ \\
\hline \multirow[t]{2}{*}{ Conspiracy } & Zika & $\begin{array}{l}\text { Zika virus is a hoax to cover up chemical teratogens manufactured by major multinational } \\
\text { corporations }\end{array}$ & $\begin{array}{l}\text { Sharma et al. 2017; } \\
\quad \text { Sommariva et al. } 2018\end{array}$ \\
\hline & & $\begin{array}{l}\text { Brain deformation/microcephaly is caused by larvicide/pesticide, not the Zika virus. It is } \\
\text { what they put in the drinking water }\end{array}$ & $\begin{array}{l}\text { Carey et al. 2020; } \\
\quad \text { Sommariva et al. 2018; } \\
\text { Wood } 2018\end{array}$ \\
\hline
\end{tabular}


Table 4 (continued)

\begin{tabular}{|c|c|c|c|}
\hline $\begin{array}{l}\text { Area of } \\
\text { misinformation }\end{array}$ & Disease & Misinformation found & Reference \\
\hline & & It is like calling a common cold an epidemic & Sommariva et al. 2018 \\
\hline & & $\mathrm{CDC}$ is likely fabricating a link between Zika virus and microcephaly cases & Sommariva et al. 2018 \\
\hline & & The virus is a bioweapon rather than a natural occurrence & Wood 2018 \\
\hline & & The Zika virus is harmless & Wood 2018 \\
\hline & & Microcephaly is caused by genetically modified mosquitoes & $\begin{array}{l}\text { Carey et al. 2020; Wood } \\
\quad 2018\end{array}$ \\
\hline & & Zika vaccine development efforts are part of a broader plan for global depopulation & Wood 2018 \\
\hline & & GMO mosquitoes spread Zika & Carey et al. 2020 \\
\hline & & Government document confirms Tdap vaccinecauses microcephaly & $\begin{array}{l}\text { Ghenai and Mejova 2017; } \\
\text { Wood } 2018\end{array}$ \\
\hline & & Zika is caused by vaccines & Klofstad et al. 2019 \\
\hline & & Zika is caused by genetically modified mosquitoes & Klofstad et al. 2019 \\
\hline & & Zika is used by governments to sicken or kill people on purpose & Klofstad et al. 2019 \\
\hline & & Zika was created to ruin the 2016 Summer Olympics in Brazil & Klofstad et al. 2019 \\
\hline & & $\begin{array}{l}\text { Zika was created by pharmaceutical companies to createdemand for a profitable vaccine or } \\
\text { drug to combat the disease }\end{array}$ & Klofstad et al. 2019 \\
\hline & & Zika is a terrorist attack & Klofstad et al. 2019 \\
\hline & & Pandemic as a way to depopulate third-world countries & Sharma et al. 2017 \\
\hline & \multirow[t]{4}{*}{ Ebola } & Ebola is a political fabrication/for financial gain by authorities or to destabilize the region & $\begin{array}{l}\text { Kasereka and Hawkes } \\
\text { 2019; Vinck et al. } 2019\end{array}$ \\
\hline & & There is a cure for Ebola but the government is keeping it from the public & Koralek et al. 2016 \\
\hline & & Government conspiracy created to eliminate a particular race & Koralek et al. 2016 \\
\hline & & EVD outbreak does not exist & Vinck et al. 2019 \\
\hline & \multirow[t]{2}{*}{ SARS } & Beijing will be barricaded in order to keep SARS out & Tai and Sun 2011 \\
\hline & & $\begin{array}{l}\text { Guangzhou banned the import and export of goods, so there wouldsoon be a shortage of } \\
\text { food }\end{array}$ & Ding 2009 \\
\hline & \multirow[t]{3}{*}{ MERS } & $\begin{array}{l}\text { Fake lists of hospitals where MERS was diagnosed and fake lists of confirmed MERS } \\
\text { patients and deaths }\end{array}$ & Song et al. 2017 \\
\hline & & A false rumour that general hospital has been shut down due to MERS cases & Song et al. 2017 \\
\hline & & Media propaganda & Alqahtani et al. 2017 \\
\hline & COVID19 & $\mathrm{N} / \mathrm{R}$ & \\
\hline & H1N1 & $\mathrm{N} / \mathrm{R}$ & \\
\hline
\end{tabular}

COVID-19 coronavirus disease 2019, EVD Ebola virus disease, GMO genetically modified organism, MERS Middle Eastern Respiratory Syndrome, N/R not reported, SARS Severe Acute Respiratory Syndrome, Tdap tetanus, diphtheria, pertussis

survey in Congo found $45.9 \%$ of people believed at least one of the following three conspiracy theories: Ebola did not exist (25.5\% believed), Ebola was a political fabrication $(32.6 \%)$ and Ebola was fabricated to destabilize the region (36.4\%) (Kasereka and Hawkes 2019).

\section{Factors that help spread belief in misinformation}

We extracted different factors associated with believing and spreading misinformation during an outbreak (Table 5).

\section{Demographic factors}

According to several studies, women and young people were most prone to believing misinformation and passing it on to others (Balami and Meleh 2019). Possessing below secondary level education was also associated with having improper knowledge about Ebola (Gidado et al. 2015). A study reported that being single (65.24\%) was related to believing misinformation more than married people (34.76\%) (Balami and Meleh 2019). 


\section{Intrapersonal factors}

One study stated that while misconceptions were associated with increased anxiety, some sort of anxiety also drove people to take preventive action (Kanadiya and Sallar 2011). Similarly, another study found that worried people were more likely to have a positive intention to take the H1N1 influenza vaccine (Naing et al. 2012).

\section{Interpersonal/social factors}

A study that conducted focus groups to determine factors that interplay with H1N1 vaccine uptake behaviour found that the 'bandwagoning' effect played a role in this context, that is, if everyone else was getting vaccinated, others followed suit; but if everyone was not, others avoided it (Boerner et al. 2013).

\section{Professional/experiential factors}

A study on physicians in Jordan found less than five years of experience as a physician was significantly related to having misinformation about the Zika virus (Abu-Rish et al. 2019). Other studies indicated that people having an academic background with a biology major (such as public health, biological sciences, biochemistry, pharmaceutical sciences and nursing) or who were in the scientific field had a lower level of misinformation than individuals from other fields, such as the arts and management sciences (Koralek et al. 2016; Pennycook et al. 2020).

\section{Information source-related factors}

Misinformation about Ebola reinforced by the media amplified unjustified fear among people (Seltzer et al. 2015; Bali et al. 2016). Studies that analysed content and responses to misinformation by the different social media platforms found that while some social media such as YouTube and Reddit reduced unreliable posts or remained neutral (Twitter), some rather amplified posts containing misinformation (Gab) (Ghenai and Mejova 2017; Bora et al. 2018; Cinelli et al. 2020).

\section{Risk communication-related factors}

One study found that two-thirds of participants $(66.5 \%)$ either believed $(27.5 \%)$ that the H1N1 vaccine was not safe or did not have any idea about its safety $(39 \%)$, which influenced over $63 \%$ of people's refusal to be vaccinated (Kanadiya and Sallar 2011). Lack of accurate public discourse about the diseases from authentic and reliable sources was also reverberated by other studies (Chew and Eysenbach 2010; Stanley et al. 2020).

\section{Government/authority-related factors}

During the SARS outbreak in 2002 in China, it was observed that when the Chinese government initially denied and remained silent about the outbreak and restricted the mainstream media from broadcasting accurate news about the SARS outbreak, various misinformation arose and caused panic and fear among people (Ding 2009; Tai and Sun 2011).

\section{Discussion}

Our rapid integrative review found that misinformation involves prevention, treatment, risk factor and disease causation, mode of transmission, complications, vaccines and conspiracy theories. Among recent large-scale infectious outbreaks, Ebola was the most commonly studied in the literature for misinformation. Women and young people were reported to be more prone to believing and passing on misinformation. Anxiety, worrying and a lack of experience in the scientific field was associated with the consumption of misinformation. Mass media, particularly social media, was largely found to contribute to the dissemination of misinformation. A lack of government efforts and a lack of trust in government efforts were also found to contribute to the spread of misinformation.

Misinformation is not only an issue during large-scale infectious disease outbreaks; the advent of the Internet and social media have exacerbated the creation and dissemination of misinformation in all areas of health (Chou et al. 2018). Social media feeds are closed networks curated to individual beliefs that amplify misinformation by creating 'information silos' and 'echo chambers'. From dangerous rumours about vaccines (Dubé et al. 2014; Ortiz-Sánchez et al. 2020), tobacco products (Albarracin et al. 2018), alternative therapies (Wilson 2002; Schmidt and Ernst 2004), and weight loss cures (Dedrick et al. 2020) to skepticism about medical guidelines (Fiscella et al. 1998), there is an ever-growing need to curb misinformation.

Most of the misinformation-related studies in this review concerned the Ebola outbreak in West Africa, and most of the articles focused on the role of social media in the spread of misinformation. These findings may indicate two things. First, social media is increasingly playing the prime role in spreading health-related misinformation, as the use of social media has become ubiquitous and the influence of social media has risen to the extreme lately (Laranjo et al. 2015). As Ebola was one of the most recent large-scale, deadly and long-lasting outbreaks before COVID-19, coupled with the growing influence of social media, concern around misinformation regarding Ebola was discussed most often. Second was the relation of health and science literacy and lack of trust in governing bodies with the spread of misinformation (Chou et al. 2018). Ebola was mainly spread in West Africa, where studies 
Table 5 Factors associated with belief and spread of misinformation

\begin{tabular}{lll} 
Categories & Misinformation believing/spreading factors & Reference \\
\hline
\end{tabular}

Demographic factors

$$
\text { Female gender }
$$

Having low level of education (less than secondary education)

Age $<30$ years, younger people

Marital status (being single)

Region of residence

Intrapersonal factors

Interpersonal/social factors

Professional/experiential factors

Information source-related

Government/authority-related

\footnotetext{
Resource/risk communication-related
}

Low institutional trust
Perceived mixed messages from different media outlets

Low level of anxiety/worry among the population regarding the disease

Lower exposure to disease-related information

Strong conspiracy mentality among individuals

Partisanship

Individuals less likely to rely on intuitions

Friends or family members discouraging vaccination by providing negative information on vaccines, sharing negative experiences with vaccines, or promoting natural or other healthy alternatives to vaccination

Physician recommended against vaccination or revealed that they were no planning to be vaccinated

Bandwagon effect (blindly following what other people do)

Less than five years of experience as a physician is related to having misinformation

Less biological science exposure

Training/occupation (arts and management sciences compared to medical, Balami and Meleh 2019 education, engineering, and other sciences occupation/professions)

Lower in basic scientific knowledge

Media reinforcing misinformation (such as presenting Ebola as highly contagious which it is not in fact)

Media coverage of the debate over vaccine safety

Media reporting was considered overhyped and sensationalistic

The lack of consistency across information from different sources

Videos/tweets from informal independent users

Family, colleagues or friends

Fast-paced social media ecosystem, where the abundance of news sources and SNS platform structures can help misinformation reach a large audience

Source, medium and tone of the information

Online discussion boards, Twitter and online cafes were more associated with misinformation than news sites and blogs

The level of control and interference of the social media platforms on shared content. While Twitter was neutral, YouTube reduces posts from unreliable sources to only $10 \%$, Reddit reduces to $50 \%$, but Gab amplifies it to $400 \%$

Public mistrust on government narratives on disease or vaccine trial

Government putting restrictions on a real news broadcast

Government's silence and denial

Lack of accurate information

Lack of public discourse about the disease or the safety and effectiveness of vaccination

People not receiving sufficient information to make an informed decision
Adebimpe et al. 2015; Gidado et al. 2015

Gidado et al. 2015; Kasereka and Hawkes 2019; Klofstad et al. 2019; Naing et al. 2012

Balami and Meleh 2019; Klofstad et al. 2019

Balami and Meleh 2019

Balami and Meleh 2019; Gidado et al. 2015

Boerner et al. 2013

Kanadiya and Sallar 2011; Naing et al. 2012

Vinck et al. 2019

Vinck et al. 2019

Klofstad et al. 2019

Klofstad et al. 2019

Pennycook et al. 2020

Boerner et al. 2013

Boerner et al. 2013

Boerner et al. 2013

Abu-Rish et al. 2019

Koralek et al. 2016

Klofstad et al. 2019

Kummervold et al. 2017

Boerner et al. 2013

Boerner et al. 2013

Boerner et al. 2013

Bora et al. 2018; Kouzy et al. 2020

Koralek et al. 2016

Sommariva et al. 2018

Balami and Meleh 2019; Seltzer et al. 2015

Song et al. 2017

Cinelli et al. 2020

Ding 2009; Kummervold et al. 2017

Tai and Sun 2011

Ding 2009

Bali et al.2016

Boerner et al. 2013; Klofstad et al. 2019

Boerner et al. 2013 
Table 5 (continued)

\begin{tabular}{|c|c|c|}
\hline Categories & Misinformation believing/spreading factors & Reference \\
\hline & $\begin{array}{l}\text { Lack of available information on an online authentic health-related plat- } \\
\text { form }\end{array}$ & Chew and Eysenbach 2010 \\
\hline & Correcting effort could confuse baseline accurate beliefs & Carey et al. 2020 \\
\hline & $\begin{array}{l}\text { Lack of government and public health authorities providing consistent, } \\
\text { clear updates and information about the disease }\end{array}$ & $\begin{array}{l}\text { Kanadiya and Sallar 2011; Kasereka and } \\
\text { Hawkes 2019; Stanley et al. } 2020\end{array}$ \\
\hline & $\begin{array}{l}\text { Lack of assessment of whether messages are being understood by the } \\
\text { target population }\end{array}$ & Kanadiya and Sallar 2011 \\
\hline & Not disclosing vaccine/trial information widely enough & Kummervold et al. 2017 \\
\hline & $\begin{array}{l}\text { A large amount of incentive for vaccine trials make people think there are } \\
\text { huge risks associated with vaccine }\end{array}$ & Kummervold et al. 2017 \\
\hline & $\begin{array}{l}\text { Lack of deeper causal explanations of the mechanisms of the pandemic } \\
\text { accessible to the layperson }\end{array}$ & Stanley et al. 2020 \\
\hline
\end{tabular}

$N / R$ not reported, SNS social networking sites

showed that the low level of health, science and overall literacy, and a high level of distrust in the government were responsible for the spread of misinformation (Fowler et al. 2014; Gostin and Friedman 2015), factors confirmed by our study.

A proactive, solution-oriented approach that dissects the different levels of misinformation and how each arises is essential to developing feasible steps to overcoming misinformation. Wardle and Derakhshan (2017) discussed the three elements involved in the creation, production, distribution and reproduction of misinformation, namely agent, message and interpreter (Fig. 2). The results of our study can be approached using this model of misinformation to identify areas for intervention. We found that agents and interpreters during both the creation and production phases included family and friends, who are often perceived as a trusted source in the absence of authoritative sources (Balami and Meleh 2019; Bali et al. 2016; Boerner et al. 2013; Koralek et al. 2016; Vinck et al. 2019). During the creation phase, individuals or informal independent online users successfully create misinformation due to the lack of competing accurate information (Wardle and Derakhshan 2017; Kouzy et al. 2020). We found women, young people, and people with low levels of information were more prone to interpreting and passing on the misinformation that had been created (Adebimpe et al. 2015; Balami and Meleh 2019; Gidado et al. 2015; Klofstad et al. 2019). During the production phase, social networks, online forums and social media ascertain misinformation and construct it into a media product (Wardle and Derakhshan 2017), which was also reflected in 14 studies included in this review. A lack of consistent authoritative information

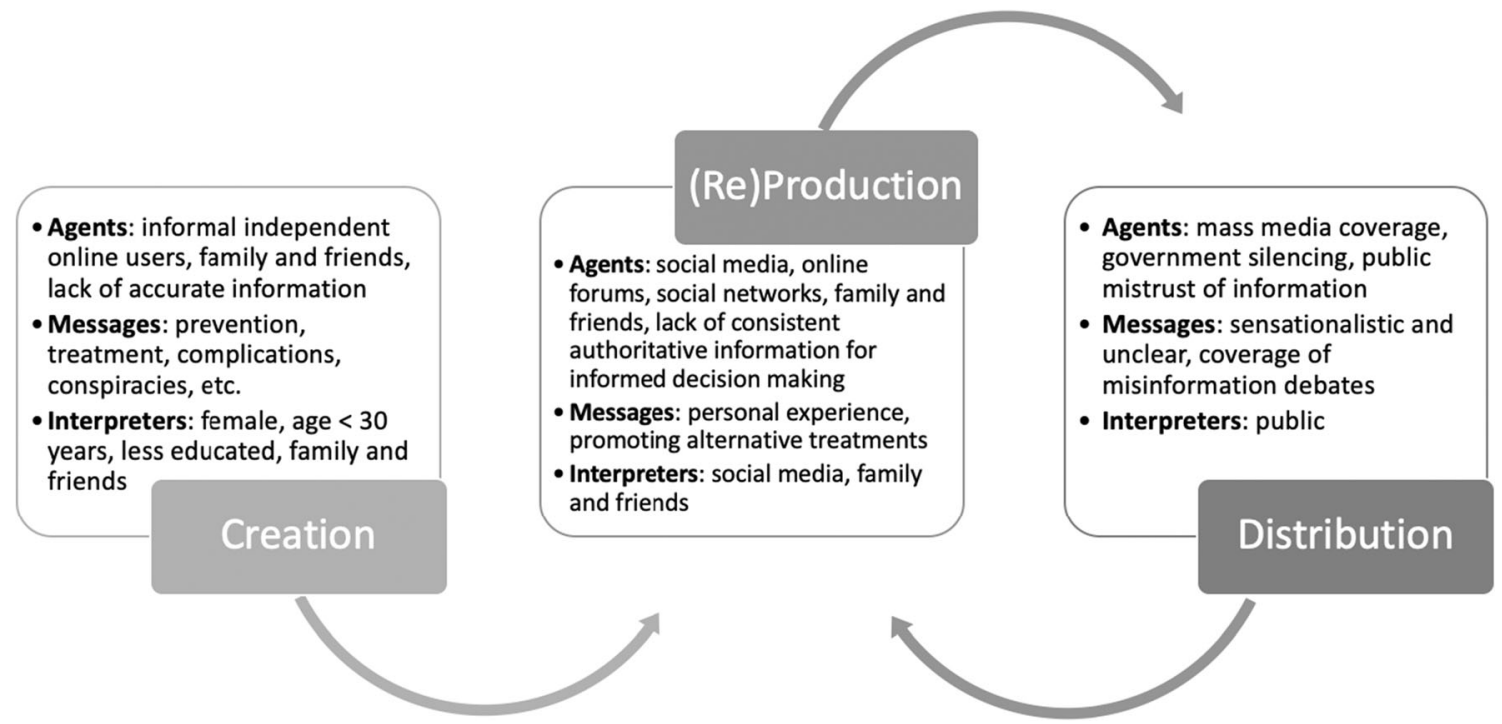

Fig. 2 Agents, messages and interpreters identified for the creation, production, distribution and reproduction of misinformation during large-scale infectious disease outbreaks 
contributes to uninformed decision-making, as trust in information becomes tied to personal experience (Wardle and Derakhshan 2017). During the distribution phase, sensationalistic or unclear mass media coverage of misinformation debates can expose the public to false claims (Wardle and Derakhshan 2017). Most of the studies in this review reported mass media as the main sources of information (Alqahtani et al. 2017); this, coupled with a lack of trust in government narratives and the disseminating power of social media, snowballs the distribution and reproduction of misinformation (Fig. 2).

Conventionally, a single database is searched in a rapid review (Tricco et al. 2015); however, we also employed a grey literature database search to help expand and strengthen our search. Nevertheless, this review also has some limitations we need to acknowledge. The inclusion criteria may have been broad, but we felt this was necessary to capture literature on the different aspects of misinformation in outbreak scenarios adequately. Furthermore, in this review, we were unable to assess the quality of the literature, due to the variability in the type of records identified in the review.

This rapid review synthesizes knowledge about the different types of misinformation that prevail among the population during a large-scale infectious disease outbreak, how it originates and spreads, which individuals are most vulnerable to misinformation, and what factors potentiate the spread and impact of misinformation. This knowledge will help guide public health bodies, governments, researchers, media and other stakeholders to control the insidious effects of misinformation during the current COVID-19 pandemic and future disease outbreaks.

\footnotetext{
Authorship contribution statement All authors contributed to the study conception and design. Developing search strategy, conducting literature search, data preparation, and analysis were performed by Nashit Chowdhury, Ayisha Khalid, and Tanvir C. Turin. The first draft of the manuscript was prepared by Nashit Chowdhury and all authors commented on previous versions of the manuscript. All authors read and approved the final manuscript.
}

Funding No funding was received for conducting this study.

\section{Declarations}

Ethics approval Not applicable.

Conflict of interest The authors have no relevant conflict of interest.

\section{References}

Abu-rish EY, Elayeh ER, Browning MJ (2019) Physicians' knowledge, attitudes and practices towards Zika virus infection in Jordan. $\mathrm{J}$ Infect Dev Ctries 13:584-590. https://doi.org/10.3855/jidc.11356
Adebimpe WO, Adeyemi DH, Faremi A, Ojo JO, Efuntoye AE (2015) The relevance of the social networking media in Ebola virus disease prevention and control in southwestern Nigeria. Pan Afr Med J 22:7. https://doi.org/10.11694/pamj.supp.2015.22.1.6165

Albarracin D, Romer D, Jones C, Hall Jamieson K, Jamieson P (2018) Misleading claims about tobacco products in YouTube videos: experimental effects of misinformation on unhealthy attitudes. J Med Internet Res 20:e229. https://doi.org/10.2196/jmir.9959

Alqahtani AS, Rashid H, Basyouni MH, Alhawassi TM, BinDhim NF (2017) Public response to MERS-CoV in the Middle East: iPhone survey in six countries. J Infect Public Health 10:534-540. https:// doi.org/10.1016/j.jiph.2016.11.015

Balami AD, Meleh HU (2019) Misinformation on salt water use among Nigerians during 2014 Ebola outbreak and the role of social media. Asian Pac J Trop Med 12:175-180. https://doi.org/10.4103/19957645.257118

Bali S, Stewart KA, Pate MA (2016) Long shadow of fear in an epidemic: Fearonomic effects of Ebola on the private sector in Nigeria. BMJ Glob Health 1:e000111. https://doi.org/10.1136/bmjgh-2016000111

Boerner F, Keelan J, Winton L, Jardine C, Driedger SM (2013) Understanding the interplay of factors informing vaccination behavior in three Canadian provinces. Hum Vaccin Immunother 9:14771484. https://doi.org/10.4161/hv.24427

Bora K, Das D, Barman B, Borah P (2018) Are internet videos useful sources of information during global public health emergencies? A case study of YouTube videos during the 2015-16 Zika virus pandemic. Pathog Glob Health 112:320-328. https://doi.org/10.1080/ 20477724.2018.1507784

Broome ME (2000) Integrative literature reviews for the development of concepts. In concept development in nursing. In: Rogers BL, Knafi KA (eds) Concept development in nursing: foundations, techniques and application 2nd edn. Saunders, Philadelphia, pp 231-250

Buli BG, Mayigane LN, Oketta JF et al (2015) Misconceptions about Ebola seriously affect the prevention efforts: KAP related to Ebola prevention and treatment in Kouroussa prefecture, Guinea. Pan Afr Med J 22:11. https://doi.org/10.11694/pamj.supp.2015.22.1.6269

Carey JM, Chi V, Flynn DJ, Nyhan B, Zeitzoff T (2020) The effects of corrective information about disease epidemics and outbreaks: evidence from Zika and yellow fever in Brazil. Sci Adv 6:eaaw7449eaaw7449. https://doi.org/10.1126/sciadv.aaw7449

Cheng VC-C, Wong S-C, Chuang VW-M et al (2020) The role of community-wide wearing of face mask for control of coronavirus disease 2019 (COVID-19) epidemic due to SARS-CoV-2. J Inf Secur 81:107-114. https://doi.org/10.1016/j.jinf.2020.04.024

Chew C, Eysenbach G (2010) Pandemics in the age of twitter: content analysis of tweets during the 2009 H1N1 outbreak. PLoS One 5: e14118. https://doi.org/10.1371/journal.pone.0014118

Chou W-YS, Oh A, Klein WMP (2018) Addressing health-related misinformation on social media. JAMA 320:2417. https://doi.org/10. 1001/jama.2018.16865

Cinelli M, Quattrociocchi W, Galeazzi A et al (2020) The COVID-19 social media infodemic. Sci Rep 10:16598. https://doi.org/10.1038/ s41598-020-73510-5

Cuan-Baltazar JY, Muñoz-Perez MJ, Robledo-Vega C, Pérez-Zepeda MF, Soto-Vega E (2020) Misinformation of COVID-19 on the internet: Infodemiology study. JMIR Public Health Surveill 6:e18444. https://doi.org/10.2196/18444

Dedrick A, Merten JW, Adams T et al (2020) A content analysis of Pinterest belly fat loss exercises: unrealistic expectations and misinformation. Am J Health Educ 51:328-337. https://doi.org/10.1080/ 19325037.2020.1795754

Ding H (2009) Rhetorics of alternative media in an emerging epidemic: SARS, censorship, and extra-institutional risk communication. Tech Commun Q 18:327-350.https://doi.org/10.1080/ 10572250903149548 
Dubé E, Vivion M, MacDonald NE (2014) Vaccine hesitancy, vaccine refusal and the anti-vaccine movement: influence, impact and implications. Expert Rev Vaccines 14:99-117. https://doi.org/10.1586/ 14760584.2015 .964212

Felter C (2020) Major epidemics of the modern era. Council on Foreign Relations. https://www.cfr.org/timeline/major-epidemics-modernera. Accessed 13 Sep 2020

Fiscella K, Franks P, Clancy CM (1998) Skepticism toward medical care and health care utilization. Med Care 36:180-189. https://doi.org/ 10.1097/00005650-199802000-00007

Fowler RA, Fletcher T, Fischer WA et al (2014) Caring for critically ill patients with Ebola virus disease: perspectives from West Africa. Am J Respir Crit Care Med 190:733-737. https://doi.org/10.1164/ rccm.201408-1514CP

Fung ICH, Fu KW, Chan $\mathrm{CH}$ et al (2016) Social media's initial reaction to information and misinformation on ebola, august 2014: facts and rumors. Public Health Rep 131:461-473. https://doi.org/10.1177/ 003335491613100312

Ghenai A, Mejova Y (2017) Catching Zika fever: application of crowdsourcing and machine learning for tracking health misinformation on twitter. In: proceedings - 2017 IEEE international conference on healthcare informatics, ICHI 2017. IEEE, p 518. https://doi. org/10.1109/ICHI.2017.58

Gidado S, Oladimeji AM, Roberts AA et al (2015) Public knowledge, perception and source of information on Ebola virus disease Lagos, Nigeria; september, 2014. PLoS Curr. https://doi.org/10. 1371/currents.outbreaks.0b805cac244d700a47d6a3713ef2d6db

Gostin LO, Friedman EA (2015) A retrospective and prospective analysis of the west African Ebola virus disease epidemic: robust national health systems at the foundation and an empowered WHO at the apex. Lancet 385:1902-1909. https://doi.org/10.1016/S01406736(15)60644-4

Haddaway NR, Collins AM, Coughlin D, Kirk S (2015) The role of Google scholar in evidence reviews and its applicability to Grey literature searching. PLoS One 10:e0138237. https://doi.org/10. 1371/journal.pone.0138237

Kanadiya MK, Sallar AM (2011) Preventive behaviors, beliefs, and anxieties in relation to the swine flu outbreak among college students aged 18-24 years. Z Gesundh Wiss 19:139-145. https://doi.org/10. 1007/s10389-010-0373-3

Kasereka MC, Hawkes MT (2019) The cat that kills people:' community beliefs about Ebola origins and implications for disease control in eastern Democratic Republic of the Congo. Pathog Glob Health 113:149-157. https://doi.org/10.1080/20477724.2019.1650227

Khangura S, Konnyu K, Cushman R, Grimshaw J, Moher D (2012) Evidence summaries: the evolution of a rapid review approach. Syst Rev 1:10. https://doi.org/10.1186/2046-4053-1-10

Khangura S, Polisena J, Clifford TJ, Farrah K, Kamel C (2014) Rapid review: an emerging approach to evidence synthesis in health technology assessment. Int J Technol Assess Health Care 30:20-27. https://doi.org/10.1017/S0266462313000664

Klofstad CA, Uscinski JE, Connolly JM, West JP (2019) What drives people to believe in Zika conspiracy theories? Palgrave Commun 5: 36. https://doi.org/10.1057/s41599-019-0243-8

Koralek T, Runnerstrom MG, Brown BJ, Uchegbu C, Basta TB (2016) Lessons from Ebola: sources of outbreak information and the associated impact on UC Irvine and Ohio University College students. PLoS Curr. https://doi.org/10.1371/currents.outbreaks. f1 f5c05c37a5ff8954f38646cfffc6a2

Kouzy R, Abi Jaoude J, Kraitem A, et al (2020) Coronavirus Goes viral: quantifying the COVID-19 misinformation epidemic on twitter. Cureus 12:e7255. https://doi.org/10.7759/cureus.7255

Kummervold PE, Schulz WS, Smout E, Fernandez-Luque L, Larson HJ (2017) Controversial Ebola vaccine trials in Ghana: a thematic analysis of critiques and rebuttals in digital news. BMC Public Health 17:642. https://doi.org/10.1186/s12889-017-4618-8
Laranjo L, Arguel A, Neves AL et al (2015) The influence of social networking sites on health behavior change: a systematic review and meta-analysis. J Am Med Inform Assoc 22:243-256. https:// doi.org/10.1136/amiajnl-2014-002841

Lau JTF, Griffiths S, Choi KC, Tsui HY (2009) Widespread public misconception in the early phase of the H1N1 influenza epidemic. J Inf Secur 59:122-127. https://doi.org/10.1016/j.jinf.2009.06.004

Miller M, Banerjee T, Muppalla R, Romine W, Sheth A (2017) What are people tweeting about Zika? An exploratory study concerning its symptoms, treatment, transmission, and prevention. JMIR Public Health Surveill 3:e38. https://doi.org/10.2196/publichealth.7157

Naing C, Tan RYP, Soon WC, Parakh J, Sanggi SS (2012) Preventive behaviours towards influenza a(H1N1)pdm09 and factors associated with the intention to take influenza a(H1N1)pdm09 vaccination. J Infect Public Health 5:412-419. https://doi.org/10.1016/j.jiph.2012. 07.005

Okan O, Bollweg TM, Berens EM et al (2020) Coronavirus-related health literacy: a cross-sectional study in adults during the COVID-19 infodemic in Germany. Int J Environ Res Public Health 17:1-20. https://doi.org/10.3390/ijerph17155503

Ortiz-Sánchez E, Velando-Soriano A, Pradas-Hernández L et al (2020) Analysis of the anti-vaccine movement in social networks: a systematic review. Int J Environ Res Public Health 17:1-11. https://doi.org/ 10.3390/ijerph17155394

Pennycook G, McPhetres J, Zhang Y, Lu JG, Rand DG (2020) Fighting COVID-19 misinformation on social media: experimental evidence for a scalable accuracy-nudge intervention. Psychol Sci 31:770780. https://doi.org/10.1177/0956797620939054

Schmidt K, Ernst E (2004) Assessing websites on complementary and alternative medicine for cancer. Ann Oncol 15:733-742. https://doi. org/10.1093/annonc/mdh174

Seltzer EK, Jean NS, Kramer-Golinkoff E, Asch DA, Merchant RM (2015) The content of social media's shared images about Ebola: a retrospective study. Public Health 129:1273-1277. https://oi.org/ 10.1016/j.puhe.2015.07.025

Sharma M, Yadav K, Yadav N, Ferdinand KC (2017) Zika virus pandemic - analysis of Facebook as a social media health information platform. Am J Infect Control 45:301-302. https://doi.org/10. 1016/j.ajic.2016.08.022

Shigemura J, Harada N, Tanichi M et al (2015) Rumor-related and exclusive behavior coverage in internet news reports following the 2009 H1N1 influenza outbreak in Japan. Disaster Med Public Health Prep 9:459-463. https://doi.org/10.1017/dmp.2015.57

Smith TO (2010) A little birdie told me: H1N1 information and misinformation exchange on Twitter. UALR - William H Bowen School of Law Legal Studies Research Paper No. 11:03

Smith PS, Torsiglieri JA, Pasley J, Esch R (2016) Stopping an epidemic of misinformation : How K - 12 Science Teachers Responded to Ebola Technical Report. http://www.horizon-research.com/ stopping-an-epidemic-of-misinformation-how-k-12-scienceteachers-responded-to-ebola-technicalreport. Accessed 13 Sep 2020

Sommariva S, Vamos C, Mantzarlis A, Đào LU-L, Martinez Tyson D (2018) Spreading the (fake) news: exploring health messages on social media and the implications for health professionals using a case study. Am J Health Educ 49:246-255. https://doi.org/10.1080/ 19325037.2018.1473178

Song J, Song TM, Seo DC, Jin DL, Kim JS (2017) Social big data analysis of information spread and perceived infection risk during the 2015 Middle East respiratory syndrome outbreak in South Korea. Cyberpsychol Behav Soc Netw 20:22-29. https://doi.org/ 10.1089/cyber.2016.0126

Stanley ML, Barr N, Peters K, Seli P (2020) Analytic-thinking predicts hoax beliefs and helping behaviors in response to the COVID-19 pandemic. Think Reason. https://doi.org/10.1080/13546783.2020. 1813806 
Tai Z, Sun T (2011) The rumouring of SARS during the 2003 epidemic in China. Sociol Health Illn 33:677-693. https://doi.org/10.1111/j. 1467-9566.2011.01329.x

Tosta E (2020) Transmission of severe acute respiratory syndrome coronavirus 2 through asymptomatic carriers and aerosols: a major public health challenge. Rev Soc Bras Med Trop 53:e20200669. https:// doi.org/10.1590/0037-8682-0669-2020

Tricco AC, Antony J, Zarin W et al (2015) A scoping review of rapid review methods. BMC Med 13:224. https://doi.org/10.1186/ s12916-015-0465-6

Van den Broucke S (2020) Why health promotion matters to the COVID19 pandemic, and vice versa. Health Promot Int 35:181-186. https:// doi.org/10.1093/heapro/daaa042

Vaska M, Chowdhury M, Naidu J, Baig K, Turin T (2019) Exploring all that is grey in the health sciences: what is grey literature and how to use it for comprehensive knowledge synthesis. J Natl Heart Foundation Bangladesh 8:14-19

Vinck P, Pham PN, Bindu KK, Bedford J, Nilles EJ (2019) Institutional trust and misinformation in the response to the 2018-19 Ebola outbreak in north Kivu, DR Congo: a population-based survey. Lancet Infect Dis 19:529-536. https://doi.org/10.1016/S1473-3099(19) 30063-5

Wang Y, McKee M, Torbica A, Stuckler D (2019) Systematic literature review on the spread of health-related misinformation on social media. Soc Sci Med 240:112552. https://doi.org/10.1016/j.socscimed. 2019.112552
Wardle C, Derakhshan H (2017) Information disorder: toward an interdisciplinary framework for research and policy making. Council of Europe. https://rm.coe.int/information-disorder-toward-aninterdisciplinary-framework-for-researc/168076277c. Accessed 13 Sep 2020

Whittemore R, Knafl K (2005) The integrative review: updated methodology. J Adv Nurs 52:546-553. https://doi.org/10.1111/j.13652648.2005.03621.x

Wilson K (2002) The desktop guide to complementary and alternative medicine: an evidence-based approach. Ann Intern Med 136:A14. https://doi.org/10.7326/acpjc-2002-136-3-a14

Wood MJ (2018) Propagating and debunking conspiracy theories on twitter during the 2015-2016 Zika virus outbreak. Cyberpsychol Behav Soc Netw 21:485-490. https://doi.org/10.1089/cyber.2017. 0669

World Health Organization (2020) Munich Security Conference. https:// www.who.int/dg/speeches/detail/munich-security-conference. Accessed 13 Sep 2020

Zarocostas J (2020) How to fight an infodemic. Lancet 395:676. https:// doi.org/10.1016/S0140-6736(20)30461-X

Publisher's note Springer Nature remains neutral with regard to jurisdictional claims in published maps and institutional affiliations. 